\title{
Bob Becking. "Mercenaries or Merchants? On the Role of Phoenicians at Elephantine in the Achaemenid Period"
}

\section{Astrid Nunn}

\author{
(2) OpenEdition \\ Journals \\ Édition électronique \\ URL : http://journals.openedition.org/abstractairanica/50022 \\ DOI : 10.4000/abstractairanica.50022 \\ ISBN : 1961-960X \\ ISSN : 1961-960X \\ Éditeur : \\ CNRS (UMR 7528 Mondes iraniens et indiens), Éditions de l'IFRI
}

Référence électronique

Astrid Nunn, « Bob Becking. "Mercenaries or Merchants? On the Role of Phoenicians at Elephantine in the Achaemenid Period" », Abstracta Iranica [En ligne], Volume 40-41 | 2019, document 79, mis en ligne le 30 octobre 2019, consulté le 23 avril 2021. URL : http://journals.openedition.org/abstractairanica/ 50022 ; DOI : https://doi.org/10.4000/abstractairanica.50022

Ce document a été généré automatiquement le 23 avril 2021.

Tous droits réservés 


\title{
Bob Becking. "Mercenaries or Merchants? On the Role of Phoenicians at Elephantine in the Achaemenid Period"
}

\author{
Astrid Nunn
}

\section{RÉFÉRENCE}

Bob Becking. "Mercenaries or Merchants? On the Role of Phoenicians at Elephantine in the Achaemenid Period", wO 47/2, 2017, p. 186-197

1 L'existence d'une garnison étrangère installée à Eléphantine pour préserver les intérêts économiques et politiques $\mathrm{du}$ Grand Roi est bien documentée. Un des groupes représentés était celui des Phéniciens. L'A. se pose la question de leur rôle particulier. Il constate par l'analyse des noms dans les textes que les Phéniciens n'étaient pas nombreux et qu'ils n'avaient pas de relation avec la garnison. Ils n'étaient donc pas soldats mais marchands et pourvoyaient la communauté, entre autres, en vin et en grain. Rien d'étonnant vu les contacts multi-millénaires entre l'Egypte et la côte phénicienne. 


\section{AUTEURS}

\section{ASTRID NUNN}

Université de Munich 